\title{
TOTAL HIP ARTHROPLASTY IN PATIENTS WITH PARKINSON'S DISEASE
}

\author{
Pradeep George Mathew ${ }^{1}$, Pavel Šponer ${ }^{1,2}$, Tomáš Kučera $^{2}$, Michal Grinac $^{1,2}$, Jiří Knižž $k^{3}$
}

Charles University in Prague, Faculty of Medicine in Hradec Králové, Czech Republic: Department of Orthopaedic Surgery', Department of Medical Biophysics ${ }^{3}$; University Hospital in Hradec Králové, Czech Republic: Department of Orthopaedic Surgery ${ }^{2}$

Summary: The aim of this study is to evaluate the results of total hip arthroplasty in patients with Parkinson's disease during a period of five years, focusing on the assessment of the risks and benefits of surgery. During this period we performed total hip arthroplasty in 14 patients (15 hips) with Parkinson's disease. Patients were evaluated by subjective symptoms and objective findings, with a focus on the use of support while walking and walking distance, severity of Parkinson's disease before surgery and at the time of the last follow-up. During the postoperative period, the following parameters were assessed: length of ICU stay, mobilization, complications, the total duration of hospitalization and follow-up care after discharge.

Of the 11 patients (12 hips) followed-up 1-5 years with an average of 3 years after operation 8 cases showed progression of neurological disability. 5 patients (6 hips) showed an increased dependence on the use of support when walking and reduced distance that the patient was able to walk. Subjectively, 10 hip joints were completely painless and 2 patients complained of only occasional mild pain in the operated hip. Complications that were encountered were urinary tract infection (5 patients), cognitive impairment ( 3 patients) and pressure ulcer ( 2 patients). We did not observe any infection or dislocation of the prosthesis. Three patients fell and fractured the femur and 3 patients in our cohort died during follow up.

Implantation of total replacement is possible with judicious indication after careful evaluation of neurological finding in patients with minimal or mild functional impairment of the locomotor system. Prerequisite for a good result is precise surgical technique and optimal implant position with balanced tension of the muscles and other soft tissues around the hip.

Key words: Total hip arthroplasty; Parkinson's disease

\section{Introduction}

Parkinson's disease is one of the most common neurological diseases with a prevalence of around 150 to 200 per 100,000 persons (20). It is a progressive neurological disease with major manifestations in the musculoskeletal system. There are four primary symptoms of Parkinson's disease. The first is the tremor, or trembling in hands, arms, legs, jaw, and face. Tremors most often occur while the individual is resting, but not while involved in a task. The second symptom is rigidity, which is an obstacle to the passive motion of the joint. The third is bradykinesia, which is slowness of voluntary movement. Over time, it may become difficult to initiate movement and to complete the movement. The fourth symptom is postural instability, which usually occurs 5-8 years after onset of illness. It is poorly amenable to treatment and leads to disturbances of balance and consequently results in frequent falls and injuries. This symptom is associated with hesitation in initiating movement or so-called braking phenomenon where a patient freezes at the start of walking or crossing the threshold. Due to the rigid stance in which the trunk, hips and knees flexed, gait is also affected. Change of attitude causes change in the center of gravity of the patient and this leads to a reduced steps and in an effort to retain the balance the patient moves faster. During walking when the patient is stopped by another person or fixed object, this leads to his fall (30).

Several studies have reported a higher risk of bone fractures in patients with Parkinson's disease compared to the general population $(11,12)$. The higher risk of fracture in these patients is due to postural instability that increases the risk of fall, reduced bone mineral density due to reduced physical activity, vitamin D deficiency from lack of exposure to UV radiation and secondarily from immobilization-induced hypercalcemia $(3,5,8,15,22)$. In the weight-bearing regions of the axial skeleton due to low mobility and limited activity, there is an increased resorption of calcium, which leads to suppression of parathyroid hormone secretion. This reduces the renal production of the active metabolite, 1,25-dihydroxyvitamin D3, which is further aggravated by deficiency resulted from malnutrition and sunlight deprivation. This results in reduced calcium 
absorption. As bone density decreases and calcium levels normalize, the compensatory hyperparathyreoidism develops leading to severe osteopenia (23). Fractures occur with increasing frequency in the spine $(3.8 \%)$, foot $(6.6 \%)$, ankle $(9.1 \%)$, ribs $(11.9 \%)$, humerus $(11.9 \%)$, distal radius (18.5\%) and hip (18.9\%) (30).

Although advancement in pharmacotherapy and surgical treatment has improved the length and quality of life in patients with Parkinson's disease, increases in life expectancy has put them in the risk of fracture, osteoarthritis and osteopenia (30). This disease in its developed form generally is contraindications for hip arthroplasty. However in practice we encounter patients suffering from Parkinson's disease with fracture of hip joint, or complications of the implanted prosthesis before the onset of neurological diseases such as symptomatic aseptic loosening or periprosthetic fracture of the femur $(16,27,28)$. In the literature only few works dealing with treatment musculoskeletal disability in Parkinson's disease has been published.

The aim of this study is to evaluate the results of total hip arthroplasty in patients with Parkinson's disease in our orthopedic practice during a period of five years, focusing on the assessment of the risks and benefits of surgery.

\section{Patients and Methods}

Over a period of five-years between January 2005 and December 2009, 1367 patients underwent primary total hip arthoplasty (THR) in our institution. In a retrospective study, we found that during this period 14 patients (15 hips) with
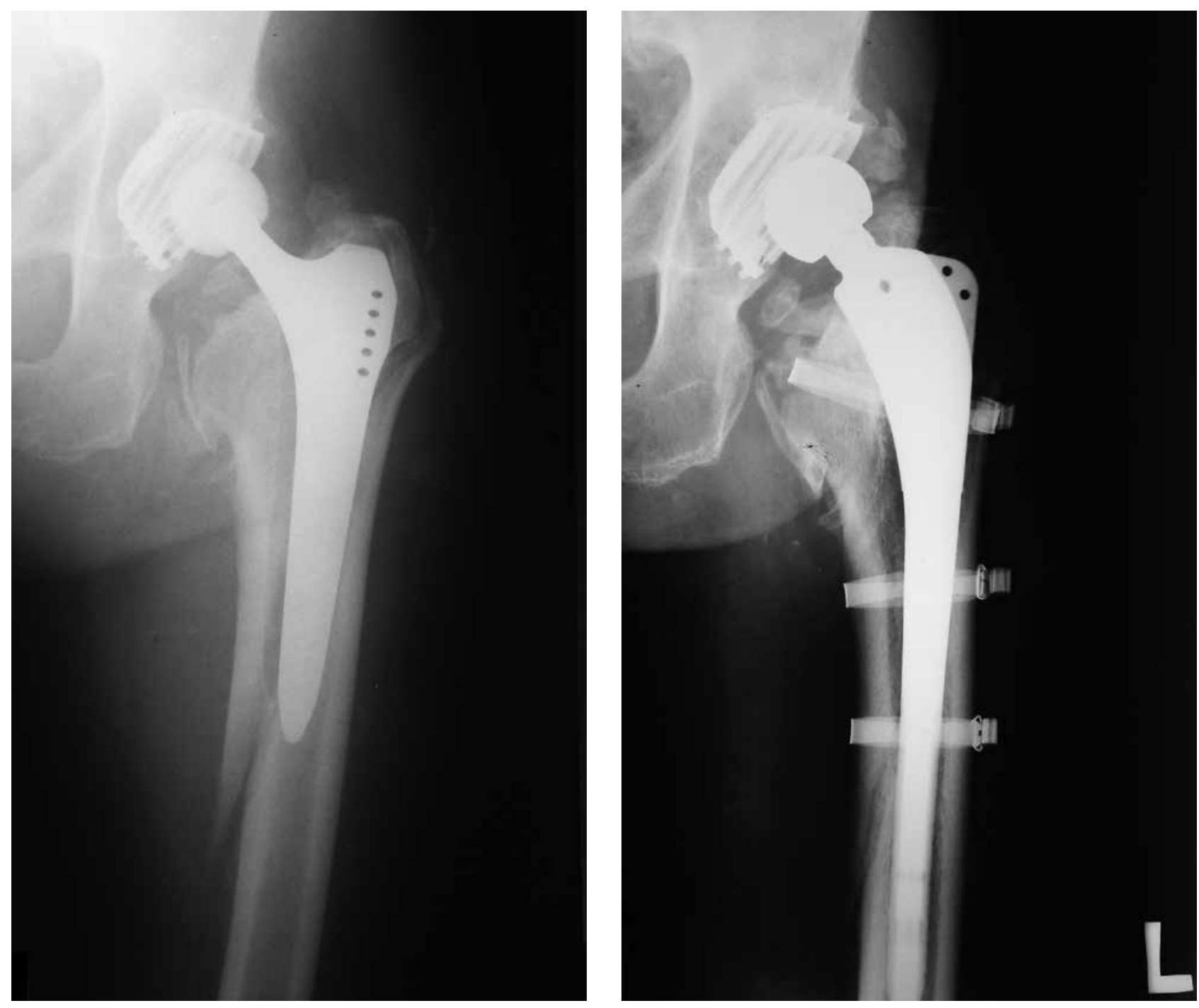

Fig. 1: (left) 83-year-old man with periprosthetic femoral fracture Vancouver B2 (unstable previously implanted primary femoral stem) on anteroposterior view before revision surgery, (right) healing of the fracture fixed with cerclage strips and osteointegration of the revision femoral cementless stem 5 months after revision surgery. 
Parkinson's disease underwent total hip replacement. This group consisted of 8 women and 6 men, whose age at the time of operation was between 66 to 83 years with an average of 76 years. 11 patients underwent primary hip replacement and the indication for surgery in 9 patients was proximal femur fracture (subcapital fracture of the femoral neck 6, mediocervical fracture of the femoral neck 1, unstable intertrochanteric fracture 2) and in 2 patients was aseptic necrosis of the femoral head with the collapse. 4 patients who had previously undergone total hip replacement, underwent revision surgery and the indication in 3 patients was aseptic loosening of the acetabular component and in 1 patient was periprosthetic femoral fracture (Fig. 1). All 11 patients undergoing primary total hip arthroplasty were operated using a standard anterolateral Watson-Jones approach, and 4 patients who underwent reimplantation were operated using Bauer's approach. Cemented acetabular components were used in 13 patients (standard implant 8, antidislocation implant 5), and a cementless socket was used in 1 patient who underwent reimplantation. In 1 patient with periprosthetic femoral fracture the previously implanted acetabular component was left in situ since it was well integrated with no signs of wear. Cemented femoral components were used in 10 patients who underwent primary replacement (standard stem 9, extreme stem 1), a cementless revision stem was used in a patient with unstable pertrochanteric fracture and in a patient with a periprosthetic fracture of the femur. In 3 patients who had undergone reimplantation of the acetabular component the femoral stem was recemented into the original cement mantle. Exact types, models and manufacturers of the implants used are introduced in Table 1. Antibiotics were administered prophylactically for 24 hours and antithrombotic prevention was ensured using low molecular weight heparin and compression stocking. Postoperative rehabili-

Tab. 1: Types, models and manufacturers of the used implants

\begin{tabular}{|l|c|l|c|}
\hline Acetabular component & \multicolumn{3}{|l|}{ Femoral component } \\
\hline Standard Cup Beznoska & 4 & $\begin{array}{l}\text { Standard Stem } \\
\text { Beznoska }\end{array}$ & 12 \\
\hline $\begin{array}{l}\text { Standard Cup ULTIMA } \\
\text { DePuy }\end{array}$ & 3 & $\begin{array}{l}\text { Extreme Stem } \\
\text { Beznoska }\end{array}$ & 1 \\
\hline Standard Cup Aesculap & 1 & & \\
\hline $\begin{array}{l}\text { Antiluxation Cup } \\
\text { Beznoska }\end{array}$ & 3 & & 1 \\
\hline $\begin{array}{l}\text { Semi-captive Cup } \\
\text { ULTIMA DePuy }\end{array}$ & 2 & & 1 \\
\hline \multicolumn{3}{|c|}{ Cementless } & $\begin{array}{l}\text { SL Revision Stem } \\
\text { Centerpulse }\end{array}$ \\
\hline TC Cup Beznoska & 1 & $\begin{array}{l}\text { Bicontact Revision } \\
\text { Stem B Braun }\end{array}$ & 1 \\
\hline Original cup left in situ &
\end{tabular}

tation was started on the first postoperative day including mobilization in vertical high walker.

Retrospective analysis was done from patient's hospital records and out patient's records to evaluate patient's subjective complaints and objective findings, focusing on the use of support while walking and walking distance preoperatively and at the time of last examination. Preoperatively the patients were evaluated for operational risk using American Society of Anesthesiologists (ASA) score and the severity of Parkinson's disease according to the classification of Columbia University, published by Margaret Hoehn and Melvin Yahr (Table 2) (14). During the postoperative period, the following parameters were assessed: length of stay in ICU, postoperative rehabilitation course mobilization, incidence of complications, the total duration of hospitalization and follow-up care after discharge. During the time of the last follow-up patients were assessed for overall mobility according to the criteria of Columbia University. Since the controversy regarding the implantation of total hip arthroplasty in patients with Parkinson's disease, the results were analyzed with special emphasis on postoperative findings and complications without comparing total joint replacement with other operating techniques. For statistical evaluation ordinal data were used for semiquantitative expressing the degree of subjective symptoms, use of support and walking distance before and after surgery. For characterization of the mean values of the random selection median was used. Wilcoxon sign test sequence pairs were tested using the null hypothesis of equality of two medians $\mathrm{HO}: \mathrm{Me}_{\text {before }}=\mathrm{Me}_{\text {after }}$ against one-sided alternative hypothesis for the pain $\mathrm{H}_{0}$ : $\mathrm{Me}_{\text {before }}>\mathrm{Me}_{\text {after }}$ and the use of support and distance while walking $\mathrm{H}_{0}: \mathrm{Me}_{\text {before }}<\mathrm{Me}_{\text {after }}$.

\section{Results}

Summary of the results of the operated patients is presented in Table 3. Length of stay in the hospital was 8-42 days with an average of 19 days. During in-hospital care, the time spend in ICU was 2-9 days with an average of 4 days, the time spend at standard orthopaedic department was 1-25 days with an average of 10 days and 5 patients with difficult postoperative physiotherapy spend 14-21 days with an

Tab. 2: Classification of severity of Parkinson's disease

\begin{tabular}{|l|l|}
\hline Severity & Characteristics \\
\hline \multirow{3}{*}{ I } & Unilateral involvement \\
\cline { 2 - 2 } & Minimal or no functional impairment \\
\hline \multirow{2}{*}{ II } & Reversible disability \\
\cline { 2 - 2 } & Intact balance \\
\hline \multirow{2}{*}{ III } & Early loss of balance \\
\cline { 2 - 2 } & Mild to moderate inability \\
\hline \multirow{2}{*}{ IV } & Severe inability \\
\cline { 2 - 2 } & Hardly able to stand or walk \\
\hline V & Confined to bed or wheel chair \\
\hline
\end{tabular}


Tab. 3: Overview of the monitored parameters in patients with Parkinson's disease

\begin{tabular}{|c|c|c|c|c|c|c|c|c|c|c|c|c|}
\hline $\begin{array}{l}\text { Patient } \\
/ \text { Sex }\end{array}$ & $\begin{array}{c}\text { Age } \\
\text { (years) }\end{array}$ & ASA & $\begin{array}{l}\text { Hoehn } \\
\text { and } \\
\text { Yahr } \\
\text { (stage) }\end{array}$ & $\begin{array}{l}\text { Dia- } \\
\text { gnosis }\end{array}$ & $\begin{array}{c}\text { Stay in } \\
\text { hospital } \\
\text { (days) }\end{array}$ & $\begin{array}{l}\text { Mobility } \\
\text { at dis- } \\
\text { charge }\end{array}$ & $\begin{array}{c}\text { Dis- } \\
\text { charged } \\
\text { to }\end{array}$ & $\begin{array}{l}\text { Compli- } \\
\text { cation }\end{array}$ & $\begin{array}{l}\text { Follow } \\
\text {-up } \\
\text { years }\end{array}$ & $\begin{array}{l}\text { Subject. } \\
\text { problem }\end{array}$ & $\begin{array}{l}\text { Ability } \\
\text { to } \\
\text { walk }\end{array}$ & $\begin{array}{l}\text { Hoehn } \\
\text { and } \\
\text { Yahr } \\
\text { (stage) }\end{array}$ \\
\hline $1 / \mathrm{M}$ & 70 & 3 & 3 & $\mathrm{SC}$ & 9 & Walker & LTS & $\begin{array}{c}\text { UTI } \\
\text { Cognitive } \\
\text { impairment }\end{array}$ & $\begin{array}{l}\text { died in } \\
6 \text { month }\end{array}$ & 0 & 0 & 0 \\
\hline $2 / \mathrm{M}$ & 75 & 2 & 3 & $\mathrm{SC}$ & 8 & Walker & LTS & $\begin{array}{c}\text { Cognitive } \\
\text { impairment } \\
\text { Periprosth. } \\
\text { femur fracture }\end{array}$ & $\begin{array}{l}\text { died in } \\
6 \text { month }\end{array}$ & 0 & 0 & 0 \\
\hline $3 / \mathrm{F}$ & 75 & 2 & 3 & $\mathrm{AL}$ & 30 & Walker & LTS & $\begin{array}{l}\text { Periprosth. } \\
\text { femur fracture }\end{array}$ & $\begin{array}{c}\text { died in } \\
2 \text { month }\end{array}$ & 0 & 0 & 0 \\
\hline $4 / F$ & 80 & 3 & 2 & $\mathrm{SC}$ & 12 & Walker & LTS & UTI & 5 & No pain & $\begin{array}{l}\text { Without } \\
\text { support }\end{array}$ & 2 \\
\hline $5 / \mathrm{M}$ & 66 & 2 & 2 & $\mathrm{AL}$ & 15 & Crutches & Home & $\begin{array}{l}\text { Decomp. } \\
\text { of DM }\end{array}$ & 5 & No pain & 1 stick & 3 \\
\hline $6 / \mathrm{M}$ & 77 & 3 & 2 & $\mathrm{AN}$ & 12 & Crutches & Home & 0 & 4 & $\begin{array}{l}\text { Mild } \\
\text { pain }\end{array}$ & $\begin{array}{l}\text { Without } \\
\text { support }\end{array}$ & 2 \\
\hline $7 / \mathrm{F}$ & 70 & 2 & 2 & $\mathrm{AL}$ & 13 & Crutches & Home & 0 & 4 & $\begin{array}{l}\text { Mild } \\
\text { pain }\end{array}$ & Crutches & 3 \\
\hline $8 / \mathrm{F}$ & 82 & 2 & 2 & AN & 23 & Crutches & Home & $\begin{array}{c}\text { Vulvovaginitis } \\
\text { sacral } \\
\text { decubitus }\end{array}$ & 2 & No pain & Crutches & 3 \\
\hline $9 / \mathrm{F}$ & 73 & 3 & 2 & $\mathrm{MC}$ & 14 & Crutches & Home & 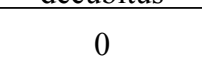 & 3 & No pain & Crutches & 3 \\
\hline $\begin{array}{l}10 / \mathrm{F} \\
\text { left }\end{array}$ & 80 & 3 & 3 & $\mathrm{SC}$ & 12 & Walker & LTS & $\begin{array}{c}\text { Pertrochanter. } \\
\text { contralateral } \\
\text { femoral frac- } \\
\text { ture }\end{array}$ & 3 & No pain & Crutches & 3 \\
\hline $\begin{array}{l}10 / F \\
\text { right }\end{array}$ & 80 & 3 & 3 & IT & 22 & Crutches & LTS & $\begin{array}{c}\text { UTI } \\
\text { Sacral } \\
\text { decubitus } \\
\end{array}$ & 3 & No pain & Crutches & 3 \\
\hline $11 / \mathrm{F}$ & 78 & 2 & 2 & IT & 42 & Walker & LTS & $\begin{array}{c}\text { UTI } \\
\text { Cognitive } \\
\text { impairment }\end{array}$ & 1 & No pain & Walker & 4 \\
\hline $12 / \mathrm{F}$ & 67 & 3 & 2 & $\mathrm{SC}$ & 12 & Walker & Home & UTI & 2 & No pain & Crutches & 3 \\
\hline $13 / \mathrm{M}$ & 83 & 3 & 2 & IT & 26 & Walker & LTS & 0 & 2 & No pain & Crutches & 3 \\
\hline $14 / \mathrm{M}$ & 77 & 3 & 3 & $\mathrm{SC}$ & 32 & Walker & LTS & 0 & 1 & No pain & Walker & 4 \\
\hline
\end{tabular}

$\mathrm{M}$ - male; F - female; MC - mediocervical fracture of the femoral neck; SC - subcapital fracture of the femoral neck; IT - intertrochanteric unstable fracture; LTS - hospitals with facilities of long term stay; UTI - urinary tract infection; $\mathrm{AL}$ - aseptic loosening of the acetabular component; AN - aseptic necrosis of the femoral head

average of 16 days at rehabilitation department. At the time of discharge 6 patients were able to walk with crutches and 9 patients walked with the help of a walker. On discharge from the hospital six patients were sent to home care, and 9 patients were transferred to hospitals with facilities of long term stay.

Complications that were encountered postoperatively are listed in Table 4. After implantation of the total endopros- thesis the complications were observed mainly in patients undergoing surgery for fracture of the proximal femur. Most common complication was urinary tract infection, which was treated with antibiotics according to the sensitivity of the pathological agent. We did not encounter any cases of dislocation of the prosthesis, deep vein thrombosis, pulmonary embolism, hematoma or wound infection. Three patients fell and fractured the femur ( 2 periprosthetic fractures, 1 un- 
Tab. 4: Overview of complications

\begin{tabular}{|l|c|c|}
\hline Complications & $\begin{array}{c}\text { Study group } \\
(15 \text { patients })\end{array}$ & $\begin{array}{c}\text { Femoral fractures } \\
(10 \text { patients })\end{array}$ \\
\hline Urinary tract infection & 5 & 5 \\
\hline Cognitive impairment & 3 & 3 \\
\hline Sacral decubitus & 2 & 1 \\
\hline Fungal vulvovaginitis & 1 & 0 \\
\hline Decompensated DM & 1 & 0 \\
\hline Total & 12 & 9 \\
\hline
\end{tabular}

stable intertrochanteric fracture on the contralateral side) during their follow-up period. All of these fractures were treated operatively. Three patients in our cohort study died (including 2 after treatment of periprosthetic fractures of the femur). Two patients out of 14 patients (15 hips) had sacral decubitus ulcer.

During the follow-up period with an average of 3 years (range 1-5 years) the progression of neurological disability in accordance with the evaluation criteria of Columbia University was recorded in 8 of the 11 patients (12 hips). Evaluation of function in 5 patients (6 hips) showed an increased dependence on the use of support while walking and reduction in the distance that the patient was able to walk. Subjectively 9 patients (10 hips) had no complaints of pain and 2 patients complained of occasional mild pain in the operated hip. Statistical evaluation using the Wilcoxon sign test serial null hypothesis was rejected at a significance level $\mathrm{p}=0.05$ in favor of the alternative hypothesis for the degree of subjective symptoms $(p=0.00065)$ and the assessment of use of support and distance while walking $(\mathrm{p}=0.042)$.

\section{Discussion}

Solution of orthopaedic problems in patients with Parkinson's disease is very challenging for associated comorbidity. For achieving of the maximal therapeutic benefit there should be good interdisciplinary cooperation in the field of orthopedics, neurology, physiotherapy and possibly neurosurgery. Although it is infrequent in practice, prior to surgery bone density should be measured for taking into account a possible fracture prevention and prevent further loss of bone mass (30). Tremor along with other symptoms in Parkinson's patients should be controlled in order to prevent postoperative complications and for improved rehabilitation. A neurologist or neurosurgeon should be consulted in order to take measures to control the symptoms of the disease.

Currently recommended treatment in patients with Parkinson's disease in acute injuries of the proximal femur is dynamic hip screw (DHS) for femoral neck fractures without dislocation and hemiarthroplasty for displaced fractures of the femoral neck, even though the outcome in patients with Parkinson's disease are not as good when compared to gen- eral population under same circumstances $(13,18,26)$. For stable intertrochantric fractures the treatment of choice is DHS and in case of unstable trochanteric fractures it is DHS with a trochanteric plate and antirotational screw, proximal femoral nail, gamma nail or other intramedullary implants $(1,17,19,24)$. In fractures of the femoral neck in our patients with Parkinson disease, the total hip arthoplasty was done instead of hemiarthroplasty since the patients had only minimal or slight musculoskeletal functional disability. In two patients with intertrochanteric fractures a total hip arthroplasty was used instead of conventional osteosynthesis since one patient had severe osteoarthritis of the hip joint, and the other patient had a contralateral proximal femoral fracture and we considered it unwise to keep the patient immobilized or load weight only on to one side.

Although the mortality rate in patients with Parkinson's disease undergoing surgery for fracture of the proximal femur is comparable to the general population, the morbidity is higher in these patients (13). Rehabilitation should be started early, as soon after postoperative stabilization of the patient in order to minimize complications and achieve the maximum degree of physical activity. According to literature, very poor results were seen after hemiarthroplasty in patients with Parkinson's disease who were not mobilized in the first week after surgery (37\% dislocation, $49 \%$ of pressure ulcers, $75 \%$ mortality) (4). In our group of operated patients, mobilization was started on the first postoperative day and there was no case of prosthesis dislocation, which can be attributed to the surgical technique, intensive postoperative rehabilitation, and patient's care. Patients should be carefully monitored to avoid common complications such as pneumonia, urinary tract infections and pressure ulcers (7). It is appropriate to meet the patient and his family to discuss the pitfalls of surgery and postoperative rehabilitation including the possible need for an extended hospital stay. The expected outcome of operative treatment is to alleviate pain, even though physical activity usually remains limited, but the patient should be able to walk, even with crutches or walker, or with help of another person. This was confirmed in our study.

There is only a few available reports on the results of total hip arthroplasty in patients with Parkinson's disease $(2,25,29)$. According to literature the rate of dislocation following arthroplasty in fracture of the femoral neck is $2-37 \%(4,7,21,26)$. An important finding in patients with Parkinson's disease is adduction contracture of the hip joint. Prior to surgery, it's not possible to evaluate abduction due to pain and muscle spasm due to fracture. It is possible that adduction contracture can be overlooked during the operation. For this reason a very careful assessment of the stability of the implanted prosthesis should be done intraoperatively. To prevent instability it is recommended to do an adductor tenotomy, and iliopsoas muscle tenotomy in cases of severe hip flexion contractures $(26,29)$. In our 5 patients antidislocation acetabular component was used. Based on perioperative evaluation, the stability of all total hip arthro- 
plasties was sufficient and no adductor muscle contracture was observed. So none of the patients in our study required an adductor tenotomy.

A high percentage of general complications reflects a significantly reduced ability of the patient to comply. Based on studies, the rate of urinary tract infections was $20 \%$ and the rate of respiratory infections was $10 \%$, which correspond to results of our study. There was reported $20-47 \%$ mortality rate in patients with Parkinson's disease who underwent joint replacement for femoral neck fracture within 6 months after surgery $(7,13,26,29)$. Above mentioned risk of death for patients proximal femoral fracture in patients with Parkinson's disease does not differ from the general population and in light of this problem it is necessary to look for the influence of age and other comorbidity $(6,10,13)$. Initially the hip arthroplasty was not recommended for the treatment of femoral neck fractures in patients with Parkinson's disease because of very high incidence of dislocation (37\%) and mortality $(75 \%)$. Deaths of all patients with dislocation of the prosthesis within 6 months after surgery was published by Coughlin (4). This observation was not confirmed in our study, but two of our patients died within 6 months after surgery for periprosthetic femoral fracture, which occured after 2 and 32 months after initial joint arthroplasty.

Even though in about $25 \%$ of patients there is inevitable progression of Parkinson's disease with severe disability or death within 5 years, after the onset of the disease and more than $80 \%$ of patients become severely handicapped or die after 10-14 years, patients with Parkinson's disease in stages I-III can be walking without or with minimal hip pain (9). The favorable functional outcome can be achieved when the total hip arthoplasty is carried out before the patient loses relatively good movement of hip and before the onset of severe osteoarthritis (29).

\section{Conclusion}

Surgical treatment in patients with Parkinson's disease is challenging due to the associated comorbidity. Despite the implementation of preventive measures, there is a high percentage of general complications, especially urinary tract infections due to inability of patients to comply. We did not encounter any case of dislocation of the prosthesis, which is often mentioned in the literature. However, the specific complications should be noted, these are periprosthetic fractures in the postoperative period resulting from falls due to the neurological disease. It is necessary to pay more attention to preventing falls and pressure sores during the postoperative period. According to literature the mortality in patients with Parkinson's disease after surgery for femoral neck fracture does not differ when compared with the general population and the hemiarthroplasty is recommended. Implantation of total hip arthroplasty is possible after a careful assessment of neurological function and indicated in patients with minimal or mild functional impairment of the musculoskeletal system. Prerequisite for a good result is precise surgical technique and the optimal position of the implanted components with a balanced tension of the muscles and other soft tissues around the hip joint.

\section{Acknowledgements}

This work was supported by the programme PRVOUK $\mathrm{P}$ 37/04 and by MHCZ - DRO (UHHK, 00179906).

\section{References}

1. Bartoníček J, Douša P, Krbec M. Osteosyntéza zlomenin proximálního konce femoru krátkým gama-hřebem. Acta Chir Orthop Traumatol Čech 1998; 65: 74-83.

2. Cabanela ME, Weber M. Total hip arthroplasty in patients with neuromuscular disease. J Bone Joint Surg 2000; 82-A: 426-32.

3. Clouston WM, Lloyd HM. Immobilization-induced hypercalcemia and regional osteoporosis. Clin Orthop Relat Res 1987; 216: 247-52.

4. Coughlin L, Tempelton J. Hip fractures in patients with Parkinson's disease. Clin Orthop Relat Res 1980; 148: 192-5.

5. Di Monaco M, Vallero F, Di Monaco R, Tappero R, Cavanna A. Bone mineral density in hip-fracture patients with Parkinson's disease: A case control study. Arch Phys Med Rehabil 2006; 87: 1459-62.

6. Džupa V, Bartoníček J, Skála-Rosenbaum J, Príkazský V. Úmrtí pacientů se zlomeninou proximálního femuru v průběhu prvního roku po úrazu. Acta Chir Orthop Traumatol Čech 2002; 69: 39-44.

7. Eventov I, Moreno M, Geller E, Tardiman R, Salama R. Hip fractures in patients with Parkinson's syndrome. J Trauma 1983; 23: 98-101.

8. Fink HA, Kuskowski MA, Orwoll ES, Cauley JA, Ensrud KE. Association between Parkinson's disease and low bone density and falls in older men: The osteoporotic fractures in men study. J Am Geriatr Soc 2005; 53: 1559-64.

9. Frassica FJ, Sim FH. Parkinson's disease. In: Morfeu BF, ed. Joint replacement arthroplasty. New York: Churchill Livingstone, 1991, 722.

10. Gallo J, Čechová I, Zapletalová J. Časné komplikace provázející TEP kyčle u fraktur krčku femuru. Acta Chir Orthop Traumatol Čech 2010; 77: 389-94.

11. Genever RW, Downes TW, Medcalf P. Fracture rates in Parkinson's disease compared with age- and gender matched controls: A retrospective cohort study. Age Ageing 2005; 34: $21-4$.

12. Johnell O, Melton LJ, Atkinson EJ, O'Fallon WM, Kurland LT. Fracture risk in patients with Parkinsonism: A population-based study in Olmsted County, Minnesota. Age Ageing 1992; 21: 32-8.

13. Hammer AJ. Intertrochanteric and femoral neck fractures in patients with parkinsonism. S Afr Med J 1991; 79: 200-2.

14. Hoehn MM, Yahr MD. Parkinsonism: onset, progression and mortality. Neurology, 1967; 17: 427-42.

15. Kao CH, Chen CC, Wang SJ, Chia LG, Yeh SH. Bone mineral density in patients with Parkinson's disease measured by dual photon absorptiometry. Nucl Med Commun 1994; 15: 173-7.

16. Krbec M, Motyčka J, Luňáček L, Douša P. Osteosyntéza periproteické suprakondylické zlomeniny kolenního kloubu s použitím LCP dlahy. Acta Chir Orthop Traumatol Čech 2009; 76: 473-8.

17. Koudela K, Kasal E, Matějka J, Vyskočil V. Geriatrická traumatologie - vize nebo skutečnost? Acta Chir Orthop Traumatol Čech. 2009; 76: 338-43.

18. Majerníček M, Dungl P, Kolman J, Malkus T, Vaculík J. Osteosyntéza intrakapsulárních zlomenin krčku stehenní kosti metodou DHS. Acta Chir Orthop Traumatol Čech 2009; 76: 319-25.

19. Pavelka T, Kortus J, Linhart M. Osteosyntéza zlomeniny proximálního femoru krátkým proximálním femorálním hřebem. Acta Chir Orthop Traumatol Čech 2003; 70: 31-8.

20. Rao G, Fisch L, Srinivasan S, et al.: Does this patient have Parkinson disease? JAMA 2003; 289: 347-53.

21. Rothermel JE, Garcia A. Treatment of hip fractures in patients with Parkinson's syndrome on levodopa therapy. J Bone Jointt Surg 1972; 54-A: 1251-4.

22. Sato Y, Kikuyama M, Oizumi K. High prevalence of vitamin D deficiency and reduced bone mass in Parkinson's disease. Neurology 1997; 49: 1273-8.

23. Sato Y, Manabe S, Kuno H, Oizumi K. Amelioration of osteopenia and hypovitaminosis D by $1 \alpha$-hydroxyvitamin D3 in elderly patients with Parkinson's disease. J Neurol Neurosurg Psychiatry 1999; 66: 64-8.

24. Skládal M, Pink M, Lisý M, Novotný L. Ošetření trochanterických zlomenin PC.C.P dlahou. Acta Chir Orthop Traumatol Čech 2009; 76: 202-7.

25. Srivastav S, Mittal V, Agarwal S. Total hip arthroplasty following failed fixation of proximal hip fractures. Indian J Orthop 2008; 42: 279-86.

26. Staeheli JW, Frassica FJ, Sim FH. Prosthetic replacement of the femoral head for fracture of the femoral neck in patients who have Parkinson disease. J Bone Joint Surg 1998; 70-A: 565-8. 
27. Št’astný E, Trč T, Frýdl J, Handl M, Kopečný Z. Reoperace při aseptickém uvolněn totální endoprotézy kyčelního kloubu. Ortopedie 2007; 1: 13-8.

28. Tomáš T, Nachtlebl L, Otiepka P. Periprotetická zlomenina distálního femuru klasifikace a terapie. Acta Chir Orthop Traumatol Čech 2010; 77: 194-202.
29. Weber M, Cabanela ME, Sim FH, Frassica FJ, Harmsen WS. Total hip replacement in patients with Parkinson's disease. Int Orthop 2002; 26: 66-8.

30. Zuckerman LM. Parkinson's disease and the orthopaedic patient. J Am Acad Orthop Surg 2009; 17: 48-55.

Received: 03/09/2012

Corresponding author:

Accepted in revised form: 19/06/2013

Assoc. Prof. Pavel Šponer, M.D., Ph.D., University Hospital in Hradec Králové, Department of Orthopaedic Surgery, Sokolská 581, 50005 Hradec Králové, Czech Republic; e-mail: sponer.p@seznam.cz 